JURNAL KEBIDANAN

Vol 6, No 3, Juli 2020 : 316-321

\title{
FAKTOR STUNTING PADA BALITA USIA 12-59 BULAN DI UPT. PUSKESMAS GEDUNG SURIAN, LAMPUNG BARAT
}

\author{
Yayang Khomsatun Khoiriah ${ }^{1}$, Yulistiana Evayanti², Ratna Dewi Putri ${ }^{3}$, Dainty Maternity ${ }^{4}$ \\ 1 UPT. Puskesmas Gedung Surian Kab. Lampung Barat \\ email: yayang.khoiria@gmail.com \\ 2,3,4Prodi Kebidanan Universitas Malahayati
}

\begin{abstract}
Background: Stunting is a condition of chronic malnutrition that occurred during the critical period of the process of growing and flowers ranging from the fetus. Stunting cases in West Lampung Regency competed in 3 consecutive years 2015-2017, by the year 2015 the number reached $28.5 \%$, stunting on 2016 reached $33.2 \%$ and in the year 2018 rose to $37.3 \%$ of the work-area of The Technical Service Unit of Gedung Surian Central Health with prevalence stuning reached $35.8 \%$ in 2018.

Purpose: in this research is to know the factors that relate to a Stunting on Toddler age 12-59 months in The Technical Service Unit of Gedung Surian Central Health, West Lampung.

Method: The design of this research is a survey technique using the analytic approach of Cross sectional Imaging in applications using statistical data (SPSS).

Result: Obtained from the processing of data using SPSS applications showed that the factors that led to the occurrence of stunting is; Birth length with the value P-Value reaches the value of 0.039, Odd-Ratio of 3.7; Birth weight with value P-Value reach 0.000, Odd-Ratio value of 0.607; and the educational level of the mother with the value $P$-Value reached 0.005 Odd-Ratio of 5.00

Conclutions: The conclusions are the relationship between birth length, birth weight, and mother's education level with the incidence of stunting in children aged 12-59 months.

Suggesstion: The incidence of stunting can be prevented by providing balanced nutrition during pregnancy and and the role of the health department to support people's knowledge to pay more attention to the nutritional adequacy of children.:
\end{abstract}

Keywords: Stunting, birth weight, birth length, Mother's known, a growing toddler.

\section{ABSTRAK}

Latar Belakang: Stunting Merupakan kondisi kekurangan gizi kronis yang terjadi pada periode kritis dari proses tumbuh dan kembang mulai dari janin. Kejadian stunting di Kabupaten Lampung Barat mengalami kenaikan pada 3 tahun berturut-turut 2015-2017, yaitu pada tahun 2015 angka stunting mencapai $28,5 \%$, pada 2016 mencapai 33,2\% dan pada tahun 2018 meningkat menjadi 37,3\% Wilayah kerja Puskesmas Gedung Surian dengan prevalensi stunting mencapai 35,8\% tahun 2018.

Tujuan: Tujuan penelitian ini untuk mengetahui Faktor-Faktor yang Berhubungan dengan Stunting pada Balita usia 12-59 Bulan di UPT. Puskesmas Gedung Surian Lampung Barat.

Metode Penelitian: Rancangan penelitian ini adalah survey analitik dengan pendekatan Cross sectional, Populasi balita umur 12-59 bulan dengan risiko stunting sebanyak 500 , sampel 84 , teknik sampling menggunakan quota sampling, pengumpulan data menggunakan kuesioner dan data sekunder, uji statistik menggunakan Chi-Square.

Hasil: Uji statistik menunjukan faktor yang berhubungan dengan stunting antara lain Panjang badan lahir dengan kejadian stunting nilai $(P-V a l u e=0,039 ; O R=3.7)$; Berat badan lahir nilai $(P$-Value $=0,000 ; O R=$ $0,607)$; Tingkat pendidikan ibu dengan nilai (P-Value $=0,005 ; O R=5,00)$;

Kesimpulan: Simpulan ada hubungan panjang badan lahir, berat badan lahir, dan tingkat pendidikan ibu dengan kejadian stunting pada balita usia 12-59 bulan.

Saran : Kejadian stunting dapat dicegah dengan pemberian gizi seimbang pada masa kehamilan dan dan peran serta dinas kesehatan mendukung pengetahuan masyarakat agar lebih memperhatikan kecukupan gizi balita.

Kata kunci: Stunting, Berat badan lahir, Panjang badan lahir, Tingkat pendidikan ibu, Pertumbuhan balita. 


\section{PENDAHULUAN}

Stunting adalah suatu kondisi kekurangan gizi kronis yang terjadi pada saat periode kritis dari proses tumbuh dan kembang mulai dari janin. Dari penelitian yang dilakukan oleh Eko Setiawan, 2018 yaitu Faktor-Faktor yang Berhubungan dengan Kejadian Stunting pada Anak Usia 24-59 Bulan di Wilayah Kerja Puskesmas Andalas Kecamatan Padang Timur Kota Padang Tahun 2018 , hasil penelitian menunjukan bahwa proporsi stunting 26,9 persen dan normal sebesar 73,1 persen dan hasil uji Chi-square menunjukkan terdapat hubungan yang bermakna antara tingkat asupan energi, riwayat durasi penyakit infeksi, berat badan lahir, tingkat pendidikan ibu dan tingkat pendapatan keluarga dengan kejadian stunting. Tingkat pendidikan ibu memiliki hubungan paling dominan dengan kejadian stunting. Prevalensi balita kerdil (stunting) 2013-2018 provinsi lampung mengalami penurunan yaitu $38,0 \%$ menjadi $34,0 \%$ namun masih masih dibawah rata-rata.(Riskesdas, 2018)

Tingkat kecerdasan anak Indonesia di urutan 64 terendah dari 65 negara asesmen yang dilakukan oleh OECD PISA (Organisation for Economic Coperation and Development Programme for International Student Assesment) suatu organisasi global bergengsi, terhadap kompetensi 510.000 pelajar usia 15 tahun dari 65 negara, termasuk Indonesia dalam bidang membaca, matematika, dan sciense. (Kementrian Keuangan, 2018)

Balita yang mengalami stunting meningkatkan risiko penurunan kemampuan intelektual, menghambatnya kemampuan motorik, produktivitas, dan peningkatan risiko penyakit degeneratif di masa mendatang.(Rochani, 2018)
Kabupaten Lampung Barat mengalami kenaikan pada 3 tahun berturut-turut 2015-2017, yaitu pada tahun 2015 angka stunting mencapai $28,5 \%$, pada 2016 mencapai $33,2 \%$ dan pada tahun 2018 meningkat menjadi 37,3\%. Untuk tahun 2018 kejadian stunting belum bisa di data sepenuhnya, sebab penderita stunting baru bisa di cek apabila masa pertumbuhan tidak bisa berkembang. Karena masa tumbuh kembang akan terdeteksi dalam kurun waktu satu tahun. UPT Puskesmas Gedung Surian merupakan satu-satunya Puskesmas yang berada di Kecamatan Gedung Surian. Wilayah kerja Puskesmas Gedung Surian dengan prevalensi stunting mencapai 35,8\% tahun 2018.

Penelitian ini bertujuan untuk mengetahui Faktor-Faktor yang berhubungan dengan Stunting pada Balita usia 12-59 Bulan di UPT. Puskesmas Gedung Surian Lampung Barat yang meliputi, riwayat status gizi ibu saat hamil (LILA), berat badan lahir pada balita, panjang lahir pada balita, ASI eksklusif, dan tingkat pendidikan ibu

\section{METODOLOGI PENELITIAN}

Rancangan penelitian ini adalah survey analitik dengan menggunakan pendekatan Cross sectional.(Notoatmodjo, 2018)

Teknik pengumpulan data berupa data sekunder dalam hal ini riwayat status gizi ibu hamil (LILA), panjang badan lahir pada balita, berat badan lahir pada balita, dan data primer berupa ASI eksklusif dan tingkat pendidikan ibu. Selanjutnya untuk menguji signifikansi apakah kedua variabel ada hubungan yang signifikan atau dengan menggunakan chi-square.

\section{HASIL DAN PEMBAHASAN}

\section{Analisis Univariat}

Tabel 1.

Distribusi Frekuensi kejadian stunting, berat badan lahir, tingkat pendidikan ibu dan panjang badan lahir UPT. Puskesmas Gedung Surian Lampung Barat

\begin{tabular}{lcc}
\hline \multicolumn{1}{c}{ Variabel } & Frekuensi & Persentase \\
\hline Distribusi Frekuensi Berat Badan Lahir & & \\
Tidak normal & 23 & 27.4 \\
Normal & 61 & 72.6 \\
Distribusi Frekuensi Tingkat Pendidikan Ibu & & \\
Pendidikan rendah & 50 & 59.5 \\
Pendidikan tinggi & 34 & 40.5 \\
Distribusi Frekuensi Panjang Badan Lahir & & \\
Tidak normal & 24 & 17.9 \\
Normal & 60 & 82.1 \\
\hline
\end{tabular}

Sumber: hasil perhitungan (2019) 
Ada Tabel 2 frekuensi berat badan lahir yang tidak normal yaitu 23 balita dengan persentase mencapai $27.4 \%$, sedangkan balita dengan berat badan lahir normal yaitu 61 balita dengan persentase $72.6 \%$ dari total 84 balita. Tabel 2 menunjukan bahwa rata-rata pendidikan ibu di wilayah penelitian berpendidikan rendah dengan frekuensi 50 responden dan persentase mencapai $59.5 \%$, dan ibu dengan pendidikan tinggi 34 responden dengan persentase $40.5 \%$. panjang badan lahir pada bayi normal mencapai 60 bayi, dengan persentase $82.1 \%$, sedangkan bayi yang mengalami panjang berat badan lahir tidak normal hanya berjumlah 24 bayi, dengan persentase 17.9\%. Pada Tabel 2 frekuensi berat badan lahir yang tidak normal yaitu 23 balita dengan persentase mencapai $27.4 \%$, sedangkan balita dengan berat badan lahir normal yaitu 61 balita dengan persentase $72.6 \%$ dari total 84 balita. Tabel 2 menunjukan bahwa rata-rata pendidikan ibu di wilayah penelitian berpendidikan rendah dengan frekuensi 50 responden dan persentase mencapai $59.5 \%$, dan ibu dengan pendidikan tinggi 34 responden dengan persentase $40.5 \%$. panjang badan lahir pada bayi normal mencapai 60 bayi, dengan persentase $82.1 \%$, sedangkan bayi yang mengalami panjang berat badan lahir tidak normal hanya berjumlah 24 bayi, dengan persentase $17.9 \%$.

Tabel 3.

Analisis Bivariat Berat Badan Lahir Panjang Badan Lahir dan Tingkat Pendidikan Ibu dengan Kejadian Stunting di UPT. Puskesmas Gedung Surian Lampung Barat.

\begin{tabular}{|c|c|c|c|c|c|c|c|c|}
\hline \multirow{3}{*}{ Variabel } & \multicolumn{4}{|c|}{ Kejadian Stunting } & \multirow{2}{*}{\multicolumn{2}{|c|}{ Jumlah }} & \multirow{3}{*}{$p$-Value } & \multirow{3}{*}{ OR } \\
\hline & \multicolumn{2}{|c|}{ Stunting } & \multicolumn{2}{|c|}{ Tidak Stunting } & & & & \\
\hline & $\mathrm{n}$ & $\%$ & $\mathrm{n}$ & $\%$ & $\mathrm{n}$ & $\%$ & & \\
\hline \multicolumn{9}{|l|}{ Berat Badan Lahir } \\
\hline Normal & 0 & 0.0 & 23 & 100 & 23 & 100 & \multirow{4}{*}{0.000} & \multirow{3}{*}{0.607} \\
\hline Tidak Normal & 24 & 39.3 & 37 & 60.7 & 61 & 100 & & \\
\hline Total & 24 & 28.6 & 60 & 71.4 & 84 & 100 & & \\
\hline \multicolumn{8}{|l|}{ Tingkat Pendidikan Ibu } & \\
\hline Pendidikan Tinggi (SMA, D3, dan S1) & 4 & 11.8 & 30 & 88.2 & 34 & 100 & \multirow{3}{*}{0.005} & \multirow{3}{*}{5.000} \\
\hline Pendidikan Rendah (SD dan SMP) & 20 & 40.0 & 30 & 60.0 & 50 & 100 & & \\
\hline \multirow{2}{*}{\multicolumn{9}{|c|}{$\begin{array}{l}\text { Panjang Badan Lahir } \\
\text { Normal }\end{array}$}} \\
\hline Normal & & & & & & & & \\
\hline Tidak Normal & 21 & 35.0 & 39 & 65.0 & 60 & 100 & \multirow[t]{2}{*}{0.039} & \multirow[t]{2}{*}{3.769} \\
\hline Total & 24 & 28.6 & 60 & 71.4 & 84 & 100 & & \\
\hline
\end{tabular}

Sumber: hasil perhitungan (2019)

Dapat dilihat pada Tabel 3 bahwa berat badan bayi normal tidak mengalami kejadian stunting, dengan kata lain persentase bayi dengan berat badan lahir normal $100 \%$ tidak mengalami kejadian stunting dengan jumlah 23 balita. Sedangkan persentase bayi dengan berat badan lahir tidak normal mengalami stunting sebesar $39.3 \%$ atau 24 dari 61 balita, dan 37 balita dengan berat badan lahir tidak normal tidak mengalami kejadian stunting atau $60.7 \%$ dari total 61 balita yang berat badan lahir tidak normal.

Lebih dalam, hasil yang didapat berdasarkan menjelaskan bahwa 20 balita mengalami stunting pada tingkat pendidikan ibu yang rendah atau $40.0 \%$ dari total 50 sampel ibu dengan pendidikan rendah, juga 30 balita atau $60.0 \%$ dari total 50 sampel. Sedangkan pada tingkat pendidikan ibu yang tinggi balita mengalami stunting hanya 4 balita ini setara dengan hanya $11.8 \%$ dari total 34 balita.
Berdasarkann data hasil analisis menggunakan aplikasi SPSS pada Tabel 10 , sesuai dengan standar yang ada pada tinjau pustaka pada penelitian ini panjang badan lahir bayi normal yaitu $>48 \mathrm{~cm}$, dengan mengacu pada standar tersebut maka dapat dilihat bahwa balita dengan panjang badan lahir normal yang mengalami kejadian stunting hanya 3 balita atau $12.5 \%$, dan balita dengan panjang badan lahir normal yang tidak mengalami kejadian stunting sebanyak 21 balita atau $87.5 \%$ dari total 24 balita. Sedangkan balita dengan panjang lahir tidak normal mengalami kejadian stunting lebih banyak yaitu 21 balita atau $35.0 \%$, dan balita dengan panjang badan lahir tidak normal yang tidak mengalami stunting yaitu 39 balita atau $65.0 \%$ dari total 60 balita. 


\section{PEMBAHASAN \\ Hubungan Berat Badan Lahir dengan Kejadian Stunting}

Analisis bivariat berat badan lahir dan kejadian stunting pada Tabel 12 di atas menunjukan bahwa berat badan lahir bayi normal (>2500 gr) berpengaruh sangat signifikan terhadap kejadian stunting pada balita dengan nilai P-Value 0,000 . Hasil ini sesuai dengan penelitian sebelumnya yang dilakukan oleh Anisa (2012), mengemukanakan bahwa terdapat hubungan yang bermakna antara berat badan lahir bayi yang tidak normal dengan kejadian stunting. Nilai Odd-Ratio pada penelitian ini yaitu 0,607, bermakna bahwa bayi dengan berat badan lahir tidak normal beresiko 0,6 kali lebih besar terkena stunting.

Berat lahir merupakan prediktor kuat terhadap penentuan ukuran tubuh di kemudian hari. Hal ini karena pada umumnya bayi yang mengalami Intra Uterine Growth Retardation (IUGR) tidak dapat mengejar pertumbuhan ke bentuk normal selama masa kanak-kanak (Barker 2008). Penyebab kelahiran bayi dengan berat badan tidak normal ini bisa dikarenakan oleh asupan nutrisi ibu pada saat kehamilan kurang baik, di daerah penelitian sendiri berdasarkan wawancara yang dilakukan pada saat pengambilan data, bahwasannya pengetahuan ibu terhadap pentingnya asupan gizi ketika hamil memang kurang baik hal ini berkenaan dengan kondisi ekonomi mayoritas pada daerah penelitian adalah menengah kebawah. Kurangnya pengetahuan ibu terhadap asupan gizi saat hamil ini bukan karena tidak adanya peyuluhan atau pemberian materi pihak dinas kesehatan setempat tentang asupan gizi seimbang bagi ibu hamil, namun karena minat dan kesadaran ibu tentang pentingnya asupan gizi seimbang demi tumbuh kembang janin yang ada dalam kandungan memang kurang baik atau bukan menjadi prioritas utama.

Asupan gizi saat kehamilan juga di bahas dalam beberapa penelitian terkait stunting salah satunya adalah Sartono, (2013) mengemukakan Kekurangan energi secara kronis menyebabkan cadangan zat gizi yang dibutuhkan oleh janin dalam kandungan tidak adekuat sehingga dapat menyebabkan terjadinya gangguan baik pertumbuhan maupun perkembangannya. Melahirkan bayi dengan berat badan lahir rendah (BBLR), Panjang badan lahir rendah dan BBLR dapat menyebabkan stunting bila asupan gizi tidak adekuat. Maka dari itu dinas kesehatan setempat harus melakukan penanganan khusus dan lebih berhati-hati terhadap mekanisme pendampingan ibu hamil dan lebih menekankan kembali tentang asupan gizi ibu hamil, demi menunjang pemenuhan kebutuhan gizi seimbang bagi janin dan sang ibu. Dengan demikian hal ini membuktikan bahwa berat badan lahir berbanding lurus terhadap asupan gizi yang seimbang, ketika bayi sedang dalam kandungan. Kejadian stunting beresiku lebih besar apabila berat badan lahir bayi kurang dari $2500 \mathrm{gr}$, hal ini berpengaruh pada tumbuh kembang balita.

\section{Hubungan Tingkat Pendidikan lbu dengan Kejadian Stunting}

Tabel 2 diatas menunjukan bahwa tingkat pendidikan ibu berpengaruh cukup signifikan terhadap kejadian stunting pada balita, dengan nilai P-Value $<0,05$ yaitu 0,005 . Sesuai dengan yang dikemukakan Hizni, et al .(2010), tingkat pendidikan dan pengetahuan ibu sangat berhubungan dengan pengetahuan gizi dan pemenuhan gizi keluarga khususnya anak, karena ibu dengan pendidikan rendah antara lain akan sulit menyerap informasi gizi sehingga dapat berisiko mengalami balita mengalami kejadian stunting. Jika pendidikan ibu dan pengetahuan ibu rendah akibatnya ia tidak mampu untuk memilih hingga menyajikan makanan untuk keluarga memenuhi syarat gizi seimbang berdasarkan hasil penelitian di atas Odd-Ratio menunjukan nilai yang cukup besar yaitu 5,000, berarti ibu dengan tingkat pendidikan yang rendah atau pengetahuan yang urang terhadap asupan gizi bagi balitanya memiliki resiko 5 kali lebih besar dibandingka ibu dengan pendidikan yang tinggi atau memiliki pengetahuan terhadap asupan gizi bagi balitanya.

Tingkat asupan gizi janin harus dimengerti oleh ibu hamil, disamping itu pada daerah penelitian rata-rata tingkat pendidikan ibu yang rendah membuat pengetahuan tentang asupan gizi seimbang saat kehamilan tidak dapat dimengerti dengan cepat, meskipun penyuluhan tentang gizi seimbang bagi ibu dan balita pada saat dalam kandungan sudah rutin diberikan ketika kegiatan posyandu dilaksanakan. Kurangnya kesadaran ibu dan daya tangkap terhadap pemenuhan gizi saat melahirkan ini menjadi perhatian khusus, karena pendampingan dinas kesehatan dengan ibu hamil tidak serta merta dapat termemonitor penuh.

\section{Hubungan Panjang Badan Lahir dengan Kejadian Stunting}

Hasil P-Value menunjukan bahwa panjang badan lahir berpengaruh signifikan karena nilai $p$ value yang didapat sebesar 0.039 atau kurang dari 0.05 , dan nilai resiko yang didapat adalah 3,7 atau bisa dibilang bayi dengan panjang badan lahir tidak 
normal beresiko 3,7 kali lebih besar terkena stunting dibandingkan dengan bayi panjang lahir normal.

Sesuai dengan teori bahwa pertumbuhan yang lambat pada bayi dipengaruhi oleh retardasi linier yang terjadi sejak dalam kandungan hal ini disebabkan karena kurangnya asupan gizi ibu sebelum masa kehamilan yang menyebabkan gangguan pertumbuhan pada janin sehingga menyebabkan panjang bayi lahir pendek. Lebih dalam Nurillah Amaliah (2016) mengemukakan hasil analisis hubungan antara panjang badan lahir dengan pertumbuhan dan perkembangan menunjukkan bahwa pada kelompok tumbuh kembang yang tidak normal, lebih banyak terjadi pada anak yang panjang badan lahirnya pendek dibandingkan anak dengan panjang badan lahir normal. Uji statistik menunjukkan bahwa ada hubungan yang signifikan antara panjang badan lahir dengan pertumbuhan dan perkembangan balita, dengan kata lain panjang badan lahir tidak normal akan berdampak pada tumbuh kembang balita dan resiko terjadinya stunting lebih besar

\section{KESIMPULAN}

Ada hubungan berat badan lahir pada balita dengan kejadian stunting di UPT.Puskesmas Gedung Surian Lampung Barat menunjukan signifikansi paling tinggi nilai (P-Value 0,000 ); (OddRatio 0,607). Ada hubungan tingkat pendidikan ibu yang rendah terhadap kejadian stunting $\mathrm{di}$ UPT.Puskesmas Gedung Surian Lampung Barat mencapai signifikansi cukup tinggi nilai ( $P$-Value 0,005); (Odd-Ratio 5,000). Ada hubungan panjang badan lahir pada balita dengan kejadian stunting di UPT.Puskesmas Gedung Surian Lampung Barat, sangat signifikan nilai $(P$-Value 0,039$)$ dan (OddRatio 3.7).

\section{SARAN}

Sebagai sumber informasi bagi masyarakat mengenai faktor yang berhubungan dengan kejadian stuting pada balita. Kejadian stunting dapat dicegah dengan menerapkan asupan gizi seimbang pada balita untuk menghindari kejadian stunting dan mengaplikasikannya.

\section{DAFTAR PUSTAKA}

Amaliah, N., Sari, K., \& Suryaputri, I. Y. (2016). Panjang Badan Lahir Pendek Sebagai Salah Satu Faktor Determinan Keterlambatan Tumbuh Kembang Anak Usia 6-23 Bulan Di Kelurahan Jaticempaka, Kecamatan Pondok Gede, Kota Bekasi. Indonesian Journal of Health Ecology, 15(1), 43-55.
Arikunto, Suharsimi. (2012). Prosedur Penelitian. Jakarta : Rineka Cipta

Dainty Maternity, S. S. T., Keb, M., \& Anjani, A. D. (2018). ASUHAN KEBIDANAN NEONATUS, BAYI, BALITA, DAN ANAK PRASEKOLAH. Penerbit Andi.

Fathonah, S. (2016). Gizi dan Kesehatan untuk Ibu Hamil. Jakarta: Erlangga.

García Cruz, L., Gonzalez Azpeitia, G., Reyes Suarez, D., Santana Rodríguez, A., Loro Ferrer, J., \& Serra-Majem, L. (2017). Factors associated with stunting among children aged 0 to 59 months from the central region of Mozambique. Nutrients, 9(5), 491.

Kementrian Keuangan. (2018). Penanganan Stunting Terpadu Tahun 2018. Jakarta : Direktur Bidang Pembangunan Manusia dan Kebudayaan.

Kesehatan, K., Penelitian, B., \& Kesehatan, P. (2018). Hasil Utama RISKESDAS 2018. Jakarta [ID]: Balitbangkes Kementerian Kesehatan.

Kemenkes RI, 2010. Keputusan menteri kesehatan RI No. 1995/Menkes/SK/XII/2010 tentang Standar Antropometri Penilaian Status Gizi Anak.

Kemenkes RI, 2018. Situasi Balita Pendek (Stunting) di Indinesia. Data dan Informasi Kesehatan, ISSN 2088-270 X. Pusat Data dan Informasi Kesehatan.

McNaughton, D. (2011). From the womb to the tomb: Obesity and maternal responsibility. Critical Public Health, 21(2), 179-190.

Nadiyah, N., Briawan, D., \& Martianto, D. (2014). Faktor Risiko Stunting Pada Anak Usia 023 Bulan Di Provinsi Bali, Jawa Barat, Dan Nusa Tenggara Timur. Jurnal Gizi dan Pangan, 9(2).

Notoatmodjo , S. (2018). Metodologi Penelitian Kesehatan. Jakarta : Rineka Cipta

Pritasari Kirana. 2018. Upaya Percepatan Penurunan Stunting : Evaluasi Pelaksanaan Tahun 2018 \& Rencana Tindak Lanjut 2019. Bogor :Direktur Jendral Kesehatan Masyarakat

Sugiyono. (2017). Metode penelitian Pendidikan Pendekatan Kuantitatif, Kualitatif, dan R\&D. Bandung Alfabeta

Proverawati, A. (2017). Anemia dan Kehamilan. Yogyakarta : Nuha Medika

Ramadani dan Ella Nurlaella Hadi, 2010. Dukungan Suami dalam Pemberian ASI Eksklusif di Wilayah Kerja Puskesmas Air Tawar Kota Padang, Sumatera Barat. 
KESMAS, Jurnal Kesehatan Masyarakat Nasional Vol. 4, No. 6.

Rochani, SKM.,MSc.,RD.dkk.2018. Stop Stunting Dengan Konseling Gizi. Jakarta: Penerbit Plus.

Sarma, H., Khan, J. R., Asaduzzaman, M., Uddin, F., Tarannum, S., Hasan, M. M., \& Ahmed, T. (2017). Factors influencing the prevalence of stunting among children aged below five years in Bangladesh. Food and nutrition bulletin, 38(3), 291-301

Satriawan, E. (2018). Strategi Nasional Percepatan Pencegahan Stunting 2018-2024. Jakata: Tim Nasional Percepatan Penanggulangan Kemiskinan (TNP2K).

Sulistyawati, A. (2014). Deteksi Tumbuh Kembang Anak. Jakarta : Salemba Medika

Winarsih. (2018). Pengantar IImu Gizi dalam Kebidanan. Yogyakarta : Pustaka Baru 